\title{
ПЛЕНКИ ДИГИДРОКВЕРЦЕТИНА: ПОЛУЧЕНИЕ И СВОЙСТВА
}

\section{А.А. Свотин, И.Д. Никитин, Р.П. Терехов, И.А. Селиванова}

Институт Фармации, ФГАОУ ВО Первый МГМУ им. Сеченова Минздрава России (Сеченовский университет),

119991, Российская Федерация, Москва, ул. Трубецкая, д.8, стр.2.

DOI: 10.19163/MedChemRussia2021-2021-406

E-mail:svotin_a_a@student.sechenov.ru

Одной из задач химико-фармацевтической разработки лекарственных средств является поиск новых функциональных материалов на основе природных соединений. На базе фармацевтической субстанции дигидрокверцетина (ДКВ) были получены модификации в виде микротрубок и липосом.

Целью работы было получение новой формы ДКВ в виде пленок и изучить ее физико-химические и ранозаживляющие свойства.

ДКВ (АО «Аметис», Россия) смешивали с L-лизином («AppliChem», Германия) в мольных соотношениях в диапазоне от 1:1 до 1:5. Композиции растворяли в воде дистиллированной, наносили на полиэтиленовую подложку и выдерживали при различных температурных режимах до формирования конечного продукта. Получены прозрачные аморфные пленки желто-оранжевого цвета, легко растворимые в воде (в терминологии ГФ РФ XIV), температура плавления составила $121 \pm 2{ }^{\circ} \mathrm{C}$.

Ранозаживляющие свойства пленок оценивали на модели ожога IIIA степени у крыс линии Wistar (табл.). Эксперимент in vivo одобрен ЛЭК Сеченовского университета (протокол №19-20 от 02.07.2020).

Таблица

Анализ ранозаживляющих свойств пленок ДКВ in vivo

\begin{tabular}{|c|c|c|c|c|c|c|c|c|}
\hline \multirow[b]{2}{*}{ Группа } & \multicolumn{6}{|c|}{ Площадь раны по дням, см² } & \multirow{2}{*}{$\begin{array}{c}\text { Средняя } \\
\text { скорость } \\
\text { зарастания } \\
\text { раны, \% }\end{array}$} & \multirow{2}{*}{\begin{tabular}{|c} 
Средний \\
день \\
$\begin{array}{c}\text { зарастания } \\
\text { раны }\end{array}$ \\
\end{tabular}} \\
\hline & 1 & 7 & 14 & 21 & 28 & 35 & & \\
\hline I & $5,5 \pm 0,4$ & $5,2 \pm 0,3$ & $4,6 \pm 0,3$ & $2,4 \pm 0,4$ & $0,8 \pm 0,3$ & $0,6 \pm 0,4$ & $2,59 \pm 0,24$ & 39 \\
\hline II & $5,3 \pm 0,2$ & $5,8 \pm 0,4$ & $4,3 \pm 0,5$ & $1,6 \pm 0,4$ & $0,5 \pm 0,1$ & $0,2 \pm 0,2$ & $2,83 \pm 0,15$ & 35 \\
\hline III & $5,8 \pm 0,4$ & $5,4 \pm 0,3$ & $4,1 \pm 0,6$ & $2,4 \pm 0,5$ & $0,4 \pm 0,1$ & $0,3 \pm 0,1$ & $2,79 \pm 0,40$ & 36 \\
\hline IV & $5,5 \pm 0,4$ & $5,4 \pm 0,3$ & $4,6 \pm 0,4$ & $2,6 \pm 0,5$ & $0,5 \pm 0,2$ & $0,3 \pm 0,1$ & $2,69 \pm 0,28$ & 37 \\
\hline $\mathrm{V}$ & $5,6 \pm 0,3$ & $5,1 \pm 0,5$ & $4,0 \pm 0,5$ & $1,9 \pm 0,6$ & $0,3 \pm 0,1$ & $0,1 \pm 0,1$ & $2,93 \pm 0,17$ & 34 \\
\hline
\end{tabular}

(Группа I - лечение отсутствует, группа II - лечение облепиховым маслом, группа III - лечение субстанцией ДКВ, группа IV - лечение субстанцией лизина, группа V - лечение полученной композицией ДКВ-Лизин в 1:5)

Результаты эксперимента показали перспективность дальнейшего изучения полученных пленок с целью разработки новых противоожоговых фитопрепаратов. 